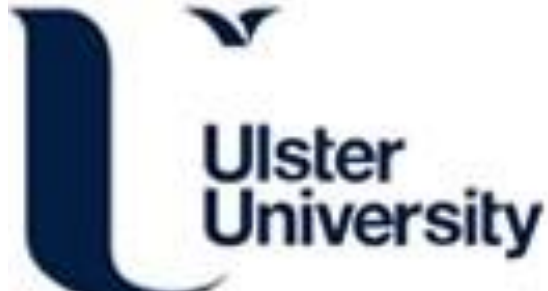

\section{Reasons why patients referred to diabetes education programmes choose not to attend: a systematic review}

Horigan, G., Davies, M., Findlay-White, F., Chaney, D., \& Coates, V. (2016). Reasons why patients referred to diabetes education programmes choose not to attend: a systematic review. Diabetic medicine, 34(1), 14-26. https://doi.org/10.1111/dme.13120

Link to publication record in Ulster University Research Portal

\section{Published in:}

Diabetic medicine

Publication Status:

Published online: 15/04/2016

DOI:

10.1111/dme. 13120

\section{Document Version}

Author Accepted version

\section{General rights}

Copyright for the publications made accessible via Ulster University's Research Portal is retained by the author(s) and / or other copyright owners and it is a condition of accessing these publications that users recognise and abide by the legal requirements associated with these rights.

\section{Take down policy}

The Research Portal is Ulster University's institutional repository that provides access to Ulster's research outputs. Every effort has been made to ensure that content in the Research Portal does not infringe any person's rights, or applicable UK laws. If you discover content in the Research Portal that you believe breaches copyright or violates any law, please contact pure-support@ulster.ac.uk. 
Patients' reasons for not attending diabetes education

The reasons patients referred to Diabetes Education programmes choose not to attend: - a systematic review

G Horigan ${ }^{1}$, M Davies ${ }^{2}$, F Findlay-White ${ }^{3}$, D Chaney ${ }^{3} \&{\text { V } \text { Coates }^{1 *}}^{*}$

${ }^{1}$ Institute of Nursing \& Health Research, University of Ulster, Magee Campus, Londonderry, N Ireland

${ }^{2}$ Department of Clinical Psychology, Belfast Health and Care Trust, N. Ireland. ${ }^{3}$ Diabetes UK Northern Ireland, Belfast, N. Ireland

Words: 4,039

*Corresponding Author

Professor Vivien Coates, ve.coates@ulster.ac.uk 
Patients' reasons for not attending diabetes education

\section{Abstract}

It is well established that diabetes education is critical to optimal diabetes care by improving metabolic control, preventing complications, improving quality of life and empowering people to make informed choices to manage their condition. Despite the significant clinical and personal rewards offered by diabetes education, programmes are underused with a significant proportion of patients choosing not to attend. This review aimed to identify the reasons those offered a place on a diabetes education programmes declined the opportunity. A systematic search of the following databases was conducted; Medline, Embase, Scopus, CINAHL and PsycINFO from 2005-2015. Studies that met the inclusion criteria focusing on patient-reported reasons for non-attendance at SDE were selected. A total of 12 studies spanning quantitative and qualitative methodologies were included. The selected studies were published in Europe, USA, Pakistan, Canada and India with a total sample size of $n=2260$. Two broad categories of non-attender were identified: 1 .Those that could not go due to logistical, medical or financial reasons (e.g. timing, costs, existing comorbidities etc). 2. Those that would not go due to a feeling of there being no perceived benefit, feel they have sufficient knowledge already or emotional and cultural reasons (e.g. no perceived problem, denial, negative feelings towards education). Diabetes education was declined for many reasons and the range of expressed reasons was more diverse and complex than anticipated. New and innovative methods of delivering diabetes education are required which address the needs of people with diabetes whilst maintaining quality and efficiency. 
Patients' reasons for not attending diabetes education

\section{Introduction}

With the world prevalence of diabetes increasing every year [1], efforts to promote diabetes education and self-management are critical to reducing the human and economic burden of this condition. High-quality structured diabetes education plays a fundamental role in improving self-management and subsequently metabolic control [2]. Evidence shows that, with reinforcement, these benefits can be maintained and can have positive effects on quality of life and health outcomes [3]. Improving knowledge, skills and confidence enables patients to take more control of their own condition and integrate effective selfmanagement into their daily lives [2,4,5]. Boren et al. (2009) [6] concluded that the benefits associated with diabetes education are positive and outweigh the costs associated with the intervention. Furthermore, it has been demonstrated that patients who did not attend any form of diabetes educational intervention had a four-fold increased risk of developing complications [7].

Diabetes education has evolved in the last fifteen years from a mainly local, ad hoc approach that was rarely underpinned by empirical theory to one in which substantial efforts have been made to ensure that diabetes education is evidence based, theory driven, delivered by trained educators, quality assured and regularly audited [8,9]. NICE guidance states that patient education programmes should meet the cultural, ethnic, linguistic, cognitive, geographical and the literacy needs of the locality. In addition all members of the healthcare team need to be familiar with the programmes available locally and these programmes must be integrated within the diabetes care pathways $[8,9]$.

Despite the demonstrable benefits of diabetes education, $[2,4,5]$, the programmes offered are underused with a significant proportion of the diabetes population not engaging either 
Patients' reasons for not attending diabetes education

by declining outright when invited to participate or by initially agreeing but then never attending.

A recent national audit in the United Kingdom (UK) [10] reported that of those diagnosed with Type 1 diabetes, education was recorded as being offered to only $2.4 \%$ of which only $1.1 \%$ were recorded as attending. Similarly in those with Type 2 diabetes $6 \%$ were recorded as being offered diabetes education of which only $1.6 \%$ was recorded as attending. In those newly diagnosed with diabetes the figures are only marginally better with $3.9 \%$ of people with Type 1 and $16.7 \%$ of people with Type 2 recorded as being offered education with only $0.9 \%$ and $3.6 \%$ respectively attending [10]. The problem of low referral rates to diabetes education, followed by a lack of uptake, appears to be of global concern. It is estimated that between $30 \%$ and $93 \%$ of eligible patients' do not to attend diabetes education with these figures varying widely within and accross countries $[11,12,13,14]$. In addition, a recent multinational study assessing psychosocial outcomes in people with diabetes showed that only $48.8 \%$ had participated in any form of educational programme. This ranged from as high as $84 \%$ in Canada to as low as $23 \%$ in India [15].

These figures are particularly concerning given the results of a recent study amongst children and adults with Type 1 diabetes conducted across 19 countries which revealed that the majority of people with Type 1 diabetes did not achieve the recommended HbA1c target of $48 \mathrm{mmol} / \mathrm{mol}-58 \mathrm{mmol} / \mathrm{mol}(6.5-7.5 \%)$, with $15-24$ year olds having higher levels than any other age group, predisposing them to future health problems $[16,17]$. This is of particular concern as young people with Type 1 diabetes are face a lifetime of diabetes selfmanagement. Although considerable progress has been made across the UK with regards to meeting clinical targets in the management of Type 2 diabetes [18] this is likely to be due to 
Patients' reasons for not attending diabetes education

the system of treating to target in general practice [19] rather than improved selfmanagement.

Many reviews published in the area of diabetes education focus on its effectiveness $[2,4,20,21]$, on attrition from programmes [22] or on psychosocial outcomes [23]. One recent review [24] did focus on barriers to attendance in diabetes education centres, however, the review included studies of patients who initially attended then subsequently dropped out of diabetes education, studies that reported healthcare professionals suggested reasons for patients' non-attendance and papers reporting the characteristics of those who did not attend. The current review is the first to focus exclusively on patients' expressed reasons for not attending diabetes education programmes.

The aim of this review is to identify the expressed reasons why patients offered a place on a diabetes education programme declined the opportunity. The findings will inform diabetes service providers, educators and commissioners of potential opportunities that may enhance uptake.

\section{Methods}

A systematic review of the literature on patients' expressed reasons for non-attendance at diabetes education was undertaken using PRISMA guidelines [25].

\section{Data Sources and Searches}

Five-electronic databases (CINHAL PLUS, EMBASE, Medline, PsychInfo and SCOPUS) were searched for the period January 2005 - June 2015. The search criteria used the following keywords or a combination of these keywords: "diabetes mellitus"; "Type 1 diabetes"; 
Patients' reasons for not attending diabetes education

"Type 2 diabetes"; "diabetes patient"; "diabetes education"; "group education"; "structured diabetes education"; "self-care; patient participation"; "patient education"; "education programme"; "refusal"; attendance"; "non-attendance"; "non-adherence"; "barriers"; "attrition"; "declining" and "disparities". Other studies were identified by manually searching reference lists of retrieved papers. The eligibility criteria for inclusion were: (1) Original research; (2) The patient sample of each study must have expressed clear reasons why they could not or would not attend SDE; (3) Published in the year range 2005-2015 (4) In the English language; (5) Full text articles.

Those studies that only reported the demographic characteristics of non-attenders rather than their expressed reasons were not included in this review, nor were those studies in which only physicians and/or educators gave their perceived reasons for patients' nonattendance. Studies reporting data on people who had partly attended and/or dropped out of structured diabetes education programmes were also excluded.

\section{Data Extraction and Analysis}

Twelve studies met the inclusion criteria and were included in this review (summarised in Table 1). Relevant data (i.e. expressed reasons given by the patient for non-attendance at diabetes education) were extracted (using a data extraction sheet developed by two of the authors GH and VC) by four of the review authors GH, FFW, DC and VC. Any differences in opinion were resolved through discussion. An iterative process was employed to review each study and an inductive methodology for thematic analysis applied to elicit patient specific reasons for not attending diabetes education. 
Patients' reasons for not attending diabetes education

\section{Results}

A total of 2073 titles and abstracts were retrieved and screened for eligibility by one researcher $(\mathrm{GH})$. After removing duplicates, $n=683$ articles were identified. This number included 8 hand-searched publications from reference lists. Of those citations $n=657$ were excluded based on title, abstract or full text content. The quality of the remaining 26 articles was appraised using the McMaster University critical review forms for quantitative and qualitative studies $[26,27]$. After consensus on eligibility was agreed by two researchers ( $\mathrm{GH}$ and $\mathrm{VC}$ ) a total of 12 studies spanning qualitative and quantitative methodologies were included in this review (Figure 1).

The studies varied in terms of design, five were of a qualitative nature $[11,28-31]$ and seven were surveys $[12,13,32-36]$. Studies were conducted across six countries (Table 1): United Kingdom 3 [12,29,30], Germany 2 [11,32], India 1 [34], Pakistan 1 [31], USA 3 [28, 35,36] and Canada $2[13,32]$. Ten of the studies were conducted in primary care or community settings $[11-13,28-30,32,33,35,36]$, one was set in a hospital out patients department [31] and one was set in a tertiary care diabetes centre [34]. The education programmes offered were mainly to those with Type 2 diabetes, however four of these studies also included programmes offered to people diagnosed with Type 1 diabetes $[31,33,35]$, those with prediabetes [33] and one study included two participants who were representing their husbands [28]. Seven of the studies included data provided by a combination of programme participants and non-participants $[13,28-32,35]$, one included data from participants, nonparticipants, educators and physicians [35] and one included non-participants, educators and education providers [36]. For the purpose of this review it was the specific reasons 
Patients' reasons for not attending diabetes education

given by those patients who did not attend diabetes education that were extracted and reviewed.

Across the 12 studies $n=2,260$ (see Table 1 ) gave specific reasons for choosing not to attend diabetes education. Seven studies reported the age range of non-attenders which spanned from 18-87 years [11,13,28-32], two studies reported mean age only which was 54 and 55 years [34,35], two studies did not report age $[12,36]$ and one study combined ages of attenders and non-attenders [33]. Of the eight studies that reported gender [13,28,31-35], $80 \%$ of non-attenders were male.

Two studies reported non-attenders to be younger, to perceive their condition as not serious or coming from higher socio-economic and income groups [13,32]. One study found non-attenders to be older [36]. In contrast one study found no difference in age, found that non-attenders were less likely to have graduated from school and were more likely to be unemployed [34]. One study found no differences in attenders and non-attenders in respect of HbA1c, blood pressure or body mass Index [32].

Five studies presented qualitative data derived from either semi-structured interviews [11,29-31] or focus groups [28]. Topic guides focused on the various aspects of living with diabetes [31], reasons for non-attendance, knowledge of diabetes, quality of life, medical background [30], preferred education/learning approaches, barriers to attendance [28], attitudes to diabetes and knowledge of diabetes education [13]. The seven quantitative studies investigated expressed reasons why people choose not to attend diabetes education, the barriers influencing attendance and factors relating to access using selfdeveloped, study specific questionnaires $[12,13,32-36]$. 
Patients' reasons for not attending diabetes education

Across the 12 studies, thirty-six separate reasons for non-attendance at diabetes education were expressed with the most frequent being: issues with timing and/or length of courses, access/transportation issues, family and work conflicts, lack of information on what the course entailed, benefits of attending not conveyed by health care professionals, patients perceiving that they already had sufficient information to self-manage their condition and contentment with information received from their GP or diabetes team.

\section{Thematic Analysis}

Two overarching themes expressed by people who chose not to attend diabetes education emerged (Table 2).

\section{Those who could not go}

For those who reported they could not attend diabetes education, their reasons could be sub-grouped into three broad categories:

- Logistical- Lack of time, transport issues, the venue was felt to be too far away, no parking at venue. Programmes were felt to be too long or scheduling of programmes was unsuitable. More pressing commitments such as work and family were prioritised over diabetes education.

- Medical- Physical disabilities or other illnesses prevented attendance or unable to attend alone.

- Financial- Insufficient health insurance cover or unable to afford travel and/or costs associated with getting to venue.

These issues are illustrated in quotes reported by qualitative studies: 
Patients' reasons for not attending diabetes education

"It was eight weeks' it's a bit hard for me to go regularly...it would be easier to take a couple days off work than it would be to attend every week for eight weeks [30]."

"No parking.....so you're talking an hour and a half on the bus [29]."

"With the angina problem I am not quite frankly capable of doing any sort of exercise...soon as they mentioned exercises and that I...no way" [30].

"Because I work nights, because my wife is disabled, I haven't even got time to go to the foot clinic. The answer would be no" [28].

"The time, work, the car, my kids" [28]

\section{Those who will not go}

The reasons for non-attendance given by those who stated that they won't go can be grouped into four broad categories.

- No perceived benefits-Some people perceived they would not benefit from attending diabetes education, or it was not seen as high priority. Lack of enthusiasm shown by the health care professionals who invited them influenced decision not to attend and some felt there was no need to attend because they were satisfied with the care they were already receiving.

- Knowledge- Some felt they knew enough already, or that they had received enough information about diabetes from other sources. Some people also reported their 
opinions were influenced by a lack of information and a number felt there was no need to be educated because they did not perceive they had a problem.

- Emotional- People reported feeling negative towards diabetes education or feeling uncomfortable about the idea of joining a group. Some also acknowledged that they preferred not to know about complications of diabetes because they would become anxious, and some were scared that they could not cope with the demands of an education course. A number also cited denial or said they did not want anyone to know they had diabetes.

- Cultural- Literacy, language and cultural issues were also cited.

Some of these issues are illustrated in quotes reported by qualitative studies:

"I have never seen a doctor about diabetes, it's always just been the nurses... there's nothing that's aroused any sense of importance, to me it's always been a minor ailment" [30]

"She (the practice nurse) said to me it was optional if I wanted to go or not, so I didn't do anything about it" [30]

"As long as my blood sugar is not too high...No, I would not yet attend it [patient education]. Unless it was rising, then I suppose I ought to attend it" [11]

"I think I prefer one to one, I don't think I prefer the group at all...I think it is erm, you know, you in a group of strangers with people you've never met before. I don't think I'll like it [29]." 
Patients' reasons for not attending diabetes education

"I don't want everybody else to know l've got diabetes...it's like letting the world know, oh I'm handicapped or disabled, you know [30]."

"Classes should be arranged for people like yourself (educated) but not for us (illiterate) it will not hold any benefit [31]."

\section{Discussion}

The purpose of this systematic review was to identify and explore the reasons so many people with diabetes choose not to attend diabetes education programmes. Our findings suggest there are a multitude of reasons why patients "cannot" or "will not" attend diabetes education. The reasons given are more diverse and complex than anticipated.

Of the studies that reported the characteristics of non-attenders compared to attenders the results were conflicting, making it difficult to reach a reliable conclusion [13,32,34]. Of note however are the studies that did report on gender [13,28,31-35], $80 \%$ of the non-attenders were male. It has previously been shown that diabetes education needs to be targeted differently to men and women [37]. There were differences across the six countries in terms of referral of patients to diabetes education. Despite whether or not attendance is made a compulsory element of statutory health insurance, differences in the costs of programmes and in health insurance rates, differing levels of illiteracy, cultural issues and the degree to which programmes were structured, many reasons for non-attendance were similar across the three continents. Many of the included studies, irrespective of country, discussed patients' already having sufficient knowledge, physicians not providing sufficient information, and family and friends being a source of knowledge as reasons for nonattendance at diabetes education $[11,12,13,31-33,35,36]$. It has been suggested that if a 
Patients' reasons for not attending diabetes education

patients' clinical results and diabetes knowledge are good then non-participation may be a justified decision [11].

Those attempting to improve rates of attendance should bear in mind that tackling one or two issues will still leave many others unaddressed and it has been demonstrated that rescheduling programmes within community settings, holding programmes at different times of the year and of the day and costs being fully compensated by health insurance companies or programmes offered free of charge does not significantly increase uptake $[2,11,28]$.

Nonetheless some recommendations can be made. The need to effectively promote and market all aspects of diabetes education was highlighted by the majority of the included studies $[11,13,29-34,36]$. When non-attenders were given more information about diabetes education many said they would be willing to attend or expressed a wish to receive more information [13].

Marketing is not a skill typically associated with healthcare professionals or healthcare services but diabetes education could be seen as a product which would benefit from an effective marketing campaign. Too many people are simply rejecting educational opportunities without fully understanding what is involved and what they might gain from attending. In addition a recent All-Party Parliamentary Group report (APPG) [38] highlighted that online resources and support groups were highly rated but patients were not being directed to them by healthcare professionals.

A report from the Department of Health patient education working group found gaps in the support needs of vulnerable groups such as people with language and literacy problems, 
Patients' reasons for not attending diabetes education

people with learning difficulties and difficult-to-reach groups such as travellers, refugees and asylum seekers. They identified that innovative approaches to diabetes education may be needed to reach these groups and suggested a variety of techniques that could be used, such as picture charts, video techniques, cartoon-based learning, text messaging and the use of e-mail tailored to the group or individual [39]. In addition an evaluation of a mobile, diabetes care, telemedicine clinic serving indigenous communities found that it improved access and was also cost-effective [40]. This method if adapted could significantly improve uptake of education in both urban and rural communities. It has also been suggested that diabetes 'burn out' which can lead to disengagement can affect uptake of education and that by offering peer support with patients who have attended education may be useful in re-engaging those who have become hard to reach [38]. While the evidence on peer support in health promotion is conflicting [41] it does appear to be effective in high risk populations [42].

Funders, educators and commissioners' need to think of ways in which diabetes education can be redesigned, marketed, timetabled and delivered whilst taking into account the views of those who have effectively rejected this product. Declining diabetes education is not a new problem and similar reasons for non-attendance were reported more than 25 years ago [43]. Given the results of the recent National Diabetes Audit, lessons have clearly not been learnt [10]. As it is impractical to provide one to one diabetes education to all or offer programmes on everyone's doorstep, other modes of delivering diabetes education to compliment what already exists are recommended. Evidence has shown that providing diabetes education programmes via video/DVD may be just as effective as group education [44-45] and Holmes et al (2012) demonstrated increased knowledge and change of attitudes 
Patients' reasons for not attending diabetes education

in women with gestational diabetes using an educational DVD [46]. Similarly, patients using a clinic based touchscreen computer system designed to assess health behaviours showed improvements in both dietary intake and cholesterol levels compared to those who did not use it [47]. A structured education programme targeted at those with Type 1 diabetes and delivered online with supplemental tutorial time was shown to increase accessibility, improve HbA1c and quality of life [48]. Such technology, if adapted and made available on mobile smartphones and/or as applications, could overcome many of the obstacles identified in this review including cultural, gender, literacy and language barriers. In addition such technology could be accessed anytime, anywhere at the users own pace and made available to large numbers of patients at minimal cost.

Several studies have reported patients' opinions on how they would like to receive information and in addition to telephone, computer websites, email, internet, books, CD, videos or DVD's other suggestions included supermarket tours, cooking classes, physical education classes and information from peers $[36,49]$. Recent evidence has demonstrated that being a member of an online diabetes forum resulted in reduced $\mathrm{HbA} 1 \mathrm{c}$ levels, improved glucose control, improved dietary choices and a better understanding and increased confidence in managing diabetes [50].

It would appear to the authors that in the last 10 years efforts to improve structured diabetes education have, for very good reasons, focused on curriculum content and quality assurance. Unfortunately ideas about how to fit diabetes education with the needs, beliefs and lives of people with diabetes have received less attention. A slightly more individualised, patient centred approach is probably required if uptake is to be enhanced. 
Patients' reasons for not attending diabetes education

\section{Quality Appraisal}

Of the twelve studies reviewed, seven were quantitative and five were qualitative in methodology. Only six reported that research ethics approval and/or patient consent was obtained. Design and methods were explained clearly, and would be replicable in most of the studies. Limitation in sampling was an issue in three of the qualitative studies. Francis et al (28) presented findings from one focus group with five participants. Whilst generalisability of findings is not the aim of qualitative studies, it is important that there is confidence that a degree of saturation in themes arising from the data has been reached. A sample of five would be unlikely to generate sufficient data to enable confidence with regards to saturation. Two other qualitative studies by Visram et al [30] and Rafique et al [31] used face to face individual interviews. Similar to the study by Francis et al [28] the principle of data saturation was not discussed. However, methods to ensure rigour were outlined, such as member checking in the coding of the data, and triangulation in data analysis.

\section{Strengths and limitations}

This review identified papers published in English language in the year range $2005-2015$. It is possible that the inclusion criteria may have excluded pertinent literature published outside of this year range and in a language other than English. A total of 12 papers were identified. Limitations in the published papers were outlined. These mainly pertained to inadequate reporting of research ethical approval processes and inadequate explanation of sampling decisions. Of particular concern is the inconsistent or absence of demographic and other characteristics of those who did not attend education programmes and this hampers attempts at future meta-analysis. Given that extensive funding is involved in commissioning diabetes self-management education programmes, this review indicates the need for robust 
Patients' reasons for not attending diabetes education

research to be undertaken pertaining to the value, benefits, attendance and attrition issues of such programmes,

\section{Conclusion}

Those who deliver diabetes education will recognise that too often there is a mismatch between priorities, needs and capabilities of the person referred and the delivery of the education course. Referrers therefore bear a heavy responsibility for ensuring that those who are referred are appropriate, ready and fully informed whilst those who provide education should ensure their courses are accessible in time and place wherever possible. The relationship between referrer and provider is therefore a crucial one. Perhaps the biggest challenge is how to make patient education more patient centred. The need for diabetes education to be curriculum (rather than patient) centred and for it to be usually commissioned and delivered in group settings promotes quality and efficiency but mitigates against flexibility to patient circumstances and needs.

\section{Funding sources}

This review is part of a wider study funded by Diabetes UK exploring engagement with structured diabetes education amongst young people with Type 1 diabetes.

\section{Competing Interests}

None 
Patients' reasons for not attending diabetes education

\section{References}

1. Geneva World health organisation. Global status report on non-communicable diseases, 2014.

2. Norris SL, Engelgau MM, Narayan KMV. Effectiveness of self-management training in type 2 diabetes: A systematic review of randomized controlled trials. Diabetes Care 2001; 24: 561-587.

3. Trento M, Gamba S, Gentile L, Grassi G, Miselli V, Morone G et al. Rethink Organization to iMprove Education and Outcomes (ROMEO): A multicentre randomized trial of lifestyle intervention by group care to manage type 2 diabetes. Diabetes Care 2010; 33: 745-747.

4. Loveman E, Frampton G, and Clegg, A J. The clinical effectiveness of diabetes education models for Type 2 diabetes: a systematic review. Health Technol Assess 2008; 12: 1-116.

5. Deakin T, McShane CE, Cade JE, Williams RD. Group based training for self-management strategies in people with type 2 diabetes mellitus. Cochrane Database Syst Rev; 2005; CD003417.

6. Boren SA, Fitzner KA, Panhalkar PS, Specker JE. Costs and benefits associated with diabetes education: A Review of the Literature. The Diabetes Educator 2009; 35: 72-96.

7. Niccoluci A, Cavaliere D, Scorpiglione N, Carinci F, Capani F, Tognoni G. A comprehensive assessment of the avoidability of long-term complications of diabetes. A case-control study Diabetes Care 1996; 19: 927-933.

8. National Institute for Clinical Excellence. Guidance on the use of patient-education models for diabetes (Technology Appraisal 60). 2003 London: NICE.

9. National Institute for Health and Clinical Excellence. The management of type 2 diabetes (update). (Clinical guideline 66.) London: NICE, 2008. www.nice.org.uk/CG66.

10. HSCIC (2014). National Diabetes Audit 2012-2013. Report 1: Care Processes and Treatment Targets. 
Patients' reasons for not attending diabetes education

11. Schäfer I, Pawels M, Küver C, Pohontsch N, Scherer M, van den Bussche H et al. Strategies for Improving Participation in Diabetes Education. A Qualitative Study PLoS ONE 2014; 9: p.e95035.

12. Wadher K. Service review of DESMOND non-attenders 2010: How attendance of structured group education for Type 2 diabetes can be improved. Birmingham, UK: Primary Care Diabetes Society, 2010.

13. Temple B, Epp D. Evaluation of a Diabetes Education Program's Non-Attendees: The Program Response. Canadian Journal of Diabetes 2009; 33: 375-380.

14. Schlundt DG, Flannery ME, Davis DL, Kinzer CK, Pichert JW. Evaluation of a multicomponent, behaviourally, problem based "summer school" programme for adolescents with diabetes. Behaviour modification 1999; 23: 79-105.

15. Nicolucci A, Kovacs Burns K, Holt RIG, Comaschi M, Hermanns N, Ishii H et al. Research: Educational and Psychological Issues Diabetes Attitudes, Wishes and Needs second study (DAWN2TM): Cross-national benchmarking of diabetes-related psychosocial outcomes for people with diabetes. Diabet Med 2013; 30: 767-777.

16. McKnight JA, Wild SH, Lamb MJE, Cooper MN, Jones TW, Davis EA. Glycaemic control of Type 1 diabetes in clinical practice early in the 21st century: an international comparison. Diabet med 2015; 32: $1036-1050$.

17. National Institute for Health and Clinical Excellence. Type 1 diabetes in adults: diagnosis and management; (guidelines NG17) August 2015.Accessed at:

http://www.nice.org.uk/guidance/ng17/resources/type-1-diabetes-in-adults-diagnosis-andmanagement-1837276469701

18. Holman N, Gadsby R, Dunn L, Sylvester C, Young B. How does current diabetes care compare with landmark clinical studies? Diabet med 2015; 32, 841-842. 
Patients' reasons for not attending diabetes education

19. Quality and Outcomes Framework (QOF) 2015-2016. Accessed at:

http://www.nhsemployers.org/your-workforce/primary-care-contacts/general-medicalservices/ /media/C68C87157A1848AD8158FACA0004DCD4.ashx

20. Clark M. Diabetes self-management education: A review of published studies. Primary Care Diabetes 2008; 2: 113-120.

21. Pottie K, Hadi A, Chen J, Welch V, Hawthorne K. Realist review to understand the efficacy of culturally appropriate diabetes education programmes. Diabet med 2013; 30: 1017-1025.

22. Gucciardi E. A systematic review of attrition from diabetes education services: Strategies to improve attrition and retention research. Canadian Journal of Diabetes 2008; 32: 53-65.

23. Steed L, Cooke D, Newman S. A systematic review of psychosocial outcomes following education, self-management and psychological interventions in diabetes mellitus. Patient Education and Counseling 2003; 51: 5-15.

24. Lawal M. Barriers to attendance in diabetes education centres: A systematic review. Diabetes and Primary Care 2015; 16: 299-306.

25. Moher D, Liberati A, Tetzlaff J, Altman DG. Preferred reporting items for systematic reviews and meta-analyses: The PRISMA statement. Ann Intern Med 2009; 151: 264-269.

26. Law M, Stewart D, Pollock N, Letts L, Bosch J, Westmorland M. Critical review form: Quantitative studies 1998; Mc Master University.

27. Letts L, Wilkins S, Law M, et al. Guidelines for critical review form: Qualitative studies (Version 2.0). Hamilton: 2007; McMaster University.

28. Francis SL. Noterman A and Litchfield R. Factors Influencing Latino Participation in CommunityBased Diabetes Education. Journal of Extension 2014; 52: 1-6. 
Patients' reasons for not attending diabetes education

29. Winkley K, Evwierhoma C, Amiel S, Lempp H, Ismail K, Forbes A. Patient explanations for nonattendance at structured diabetes education sessions for newly diagnosed Type 2 diabetes: a qualitative study. Diabet Med 2014; 32: 120-128.

30. Visram S, Bremner A, Harrington B, Hawthorne G. Factors affecting uptake of an education and physical activity programme for newly diagnosed type 2 diabetes. European Diabetes Nursing 2008; 5: 17-22.

31. Rafique, $G$ and Shaikh, F. Identifying needs and barriers to diabetes education in patients with diabetes. J Pak Med Assoc 2006; 56: 347-352.

32. Schäfer I, Küver C, Wiese B, Pawels $M$, van den Bussche $H$, et al. Identifying groups of nonparticipants in type-2-diabetes education. Am J Manag Care 2013; 19: 499-506.

33. Gucciardi E, Chan V, Lo B, Fortugno M, Horodezny S, Swartzack S. Patients' Perspectives on Their Use of Diabetes Education Centres in Peel-Halton Region in Southern Ontario. Canadian Journal of Diabetes 2012; 36: 214-217.

34. Shaji S, Kumpatia S, Viswanathan V. Bias and Barriers Influencing Patients' Attendance Towards Diabetes Education Programme. TAPI Journal 2012; 4: 1-7. Accessed at:

\section{http://www.mvdiabetes.com/images/pdf/12-TAPIJ-4(3)-ser-dec-2012.pdf}

35. Peyrot M, Rubin RR, Funnell MM, Siminerio LM. Access to Diabetes Self-Management education; Results of National Surveys of patients, educators and physicians. The diabetes educator 2009; 35 : 246-262.

36. Diabetes Self-Management Education Barrier- Study Sept 2006-Maine department of health and human services, 2006. Accessed at:

https://www1.maine.gov/dhhs/mecdc/phdata/non-dhp-pdf-doc/diabetes-self-managmenteducation-barrier-study-september-.pdf 
Patients' reasons for not attending diabetes education

37. Gucciardi, Enza, et al. "Characteristics of men and women with diabetes Observations during patients' initial visit to a diabetes education centre." Canadian Family Physician 54.2 (2008): 219227.

38. Taking Control: Supporting people to self-manage their diabetes; All-Party Parliamentary Group for Diabetes report. March 2015. Accessed at:

https://jdrf.org.uk/wp-content/uploads/2015/10/APPG-Diabetes-Report-Education-Final-Report.pdf 39. Structured Patient Education in Diabetes Report from the Patient Education Working Group. Department of Health and Diabetes UK 2005. Accessed at:

\section{https://www.diabetes.org.uk/Documents/Reports/StructuredPatientEd.pdf}

40. Jin AJ, Martin D, Maberley D, Dawson KG, Seccombe DW, Beattie J. Evaluation of a mobile diabetes care telemedicine clinic serving Aboriginal communities in Northern British Columbia, Canada. Int J Circumpolar Health 2004; 63: 124-8.

41. Tang TS, Ayala GX, Cherrington A, Rana G. Review of Volunteer-Based Peer Support Interventions in Diabetes. Diabetes Spectrum 2011; 24: 85-98.

42. Philis-Tsimikas, Fortmann A, Lleva-Ocana L, WALKER C, GALLO LC. Peer-Led Diabetes Education Programs in High-Risk Mexican Americans Improve Glycemic Control Compared With Standard Approaches. Diabetes Care 2011; 34: 1926-1931.

43. Russell Glasgow, Deborah Toobert, Sarah Hampson. Participation in Outpatients Education Programs: How many patients take part and how representative are they? The Diabetes Educator 1991; 17: 376-380.

44. Cordina M, McElnay JC, Hughes CM. 'Assessment of a community pharmacy-based program for patients with asthma.' Pharmacotherapy 2001; 21: 1196-1203. 
Patients' reasons for not attending diabetes education

45. Samoocha D, Bruinvels DJ, Elbers NA, Anema JR, van der Beek AJ. 'Effectiveness of web-based interventions on patient empowerment: a systematic review and meta-analysis.' J Med Internet Res 2010; 12: e23.

46. Holmes V, McCance D, Patterson C, Harper R, Alderdice F, Spence M. Evaluation of a DVD for women with diabetes: impact on knowledge and attitudes to preconception care. Diabetic Medicine 2012; 29: 950-95627.

47. Glasgow RE, La Chance PA, Toobert D, Brown J, Hampson SE, Riddle MC. Long term effects and costs of brief behavioural dietary intervention for patients with diabetes delivered from the medical office. Patient Education and Counseling 1997; 32: 175-184.

48. Fearnley L, Dornhorst A, Oliver N. Online structured education for people with type 1 diabetes. Journal of Diabetes Nursing 2012; 16:379.

49. Peyrot M, Ruben R. Access to Diabetes Self-Management Education. Diabetes Educ 2008; 34:

90-97.

50. Diabetes.co.uk Forum M12 2013 Survey. 
Figure1. Flow diagram to show results of searches for systematic review.

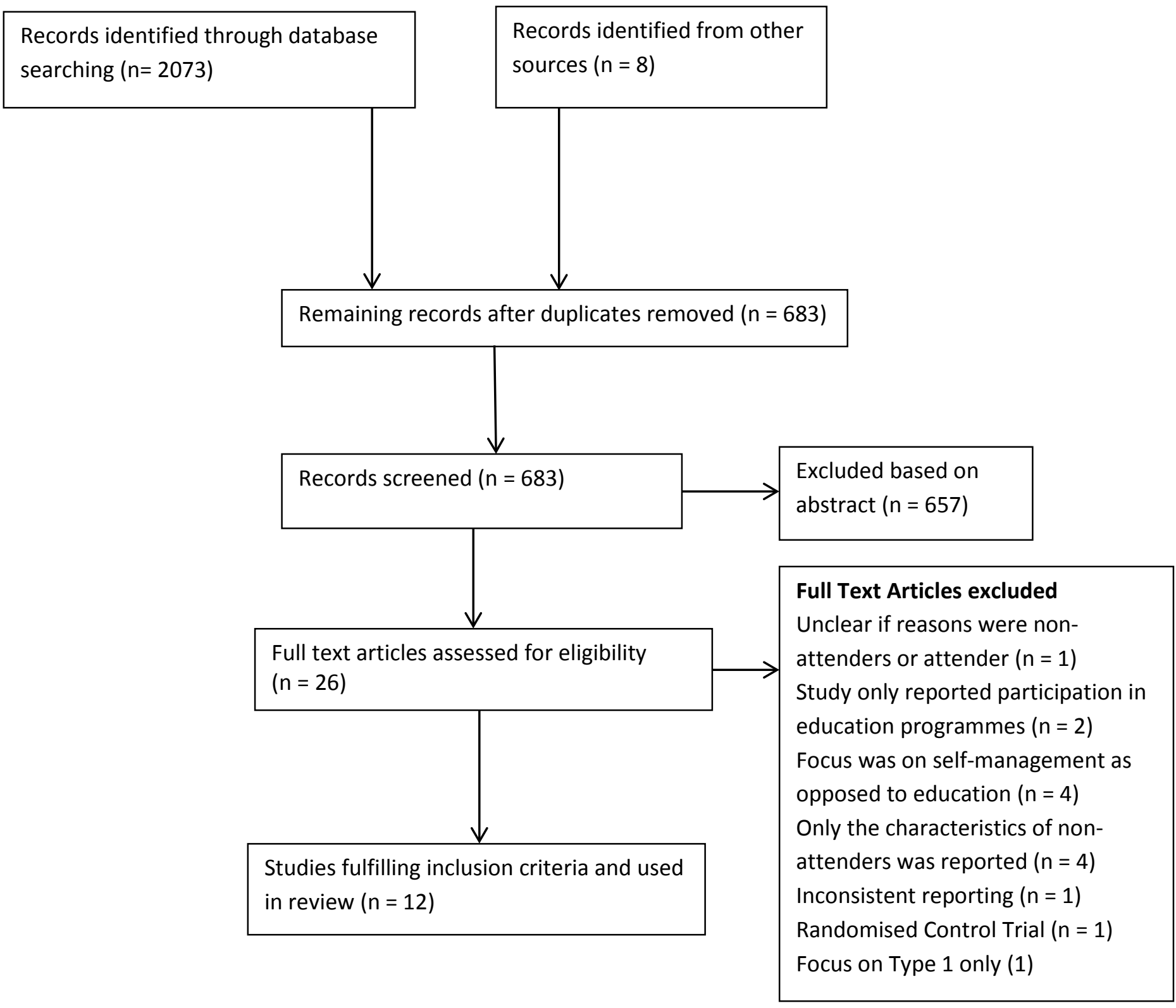


Table 1. A summary of the study characteristics and main findings of the articles included in the systematic review.

\begin{tabular}{|c|c|c|c|c|c|}
\hline $\begin{array}{l}\text { Author, year } \\
\text { published and } \\
\text { setting }\end{array}$ & $\begin{array}{l}\text { Study period, design \& purpose, selection of } \\
\text { cases, methods of data collection }\end{array}$ & $\begin{array}{c}\text { Cost of } \\
\text { programme } \\
\text { to patient }\end{array}$ & $\begin{array}{c}\text { Non- } \\
\text { attendees } \\
\text { only }\end{array}$ & Outcomes, results & Limitations \\
\hline $\begin{array}{l}\text { Francis et al, } \\
\text { (2014), } \\
\text { USA } \\
{[28]}\end{array}$ & $\begin{array}{l}\text { No study period reported. Qualitative study } \\
\text { which aimed to examine the factors that } \\
\text { influence low participation rates in a Latino } \\
\text { community based diabetes education } \\
\text { programme. } n \text { = } 5 \text { participants who initially } \\
\text { expressed an interest in the revised Dining with } \\
\text { Diabetes (DWD) education programme (adopted } \\
\text { by } 6 \text { US States as it has been shown to reduce } \\
\text { HbA1c levels) were invited and asked to complete } \\
\text { a socio-demographic and diabetes self- } \\
\text { management questionnaire and participate in a } 1 \\
\text { hour focus group which among other topics } \\
\text { included barriers to attendance. The focus group } \\
\text { was conducted in Spanish, recorded, transcribed } \\
\text { and analysed for common themes. General } \\
\text { descriptive statistics were used assess } \\
\text { questionnaire responses. }\end{array}$ & $\begin{array}{l}\text { DWD } \\
\text { education } \\
\text { programmes } \\
\text { are provided } \\
\text { at a low or } \\
\text { no cost (for } \\
\text { this } \\
\text { particular } \\
\text { programme } \\
\text { there was no } \\
\text { cost). } \\
\text { Insurance is } \\
\text { not required } \\
\text { for people to } \\
\text { attend the } \\
\text { programs. }\end{array}$ & $(n=5)$ & $\begin{array}{l}\text { Reported barriers for non- } \\
\text { attendance at the Dining } \\
\text { with Diabetes programme } \\
\text { included limited time, family } \\
\text { and work conflicts, viewing } \\
\text { DWD as a low priority and } \\
\text { access issues. In addition } \\
\text { limited use of culturally } \\
\text { preferred marketing was } \\
\text { seen as a barrier. }\end{array}$ & $\begin{array}{l}\text { Small sample size of one small focus } \\
\text { group. Ethical approval not discussed } \\
\text { however, consent was obtained from } \\
\text { participants. }\end{array}$ \\
\hline $\begin{array}{l}\text { Winkley et al, } \\
\text { (2014) } \\
\text { United Kingdom } \\
{[29]}\end{array}$ & $\begin{array}{l}\text { 2008-2011. Qualitative study of a purposeful } \\
\text { sample of non-attenders ( } n=30 \text { ) from a previous } \\
\text { study in South London by the same authors which } \\
\text { had recruited a cohort of people newly diagnosed } \\
\text { with Type } 2 \text { diabetes who were offered } \\
\text { DESMOND Programme. The aim of this study was } \\
\text { to examine key themes for non-attendance } \\
\text { (which is as high as } 65 \% \text { ) at structured diabetes } \\
\text { education using semi-structured interviews. } \\
\text { Patients were sampled according to their age ( } 3 \\
\text { age groups } \leq 45 \text { years, } 46-59 \text { years and } 60 \text { years), } \\
\text { gender, self-reported ethnicity and borough of }\end{array}$ & No cost & $(n=30)$ & $\begin{array}{l}\text { Three main themes emerged } \\
\text { explaining reasons for non- } \\
\text { attendance at structured } \\
\text { diabetes education. } \\
\text { 1) Lack of } \\
\text { information/perceived benefit } \\
\text { of programme, 2) Unmet } \\
\text { personal preferences (e.g. } \\
\text { parking, timing) and } 3 \text { ) shame } \\
\text { and stigma of diabetes } \\
\text { (appeared to be a cultural } \\
\text { issue). }\end{array}$ & $\begin{array}{l}\text { Participants were coded as } \\
\text { non-attenders if they had no } \\
\text { recollection of being informed of } \\
\text { diabetes education. }\end{array}$ \\
\hline
\end{tabular}




\begin{tabular}{|c|c|c|c|c|c|}
\hline & $\begin{array}{l}\text { residence in South London. A thematic } \\
\text { framework method was applied to analyse the } \\
\text { data. }\end{array}$ & & & & \\
\hline $\begin{array}{l}\text { Schäfer et al, } \\
\text { (2014) Germany } \\
\text { [11] }\end{array}$ & $\begin{array}{l}\text { 2010. Qualitative study, aiming to examine } \\
\text { patients' attitudes towards diabetes education in } \\
\text { order to identify the barriers as to why } \approx 30-50 \% \\
\text { do not participate. } n=18 \text { adult patients } \\
\text { diagnosed with Type } 2 \text { diabetes who had enrolled } \\
\text { in a disease management programme and who } \\
\text { had no prior attendance at a diabetes education } \\
\text { course were contacted from purposively selected } \\
\text { GP practices and partook in semi-structured face } \\
\text { to face interviews. Interviews were audiotaped. }\end{array}$ & $\begin{array}{l}\text { Fully } \\
\text { compensated } \\
\text { by German } \\
\text { Statutory } \\
\text { Health } \\
\text { Insurance }\end{array}$ & $(n=14)$ & $\begin{array}{l}12 \text { reasons for non-participation } \\
\text { in diabetes education were } \\
\text { identified that fell into } 4 \\
\text { themes: Physician's influence, } \\
\text { State of health condition, } \\
\text { Avoidance and refusal, } \\
\text { Knowledge and activity. }\end{array}$ & $\begin{array}{l}\text { Only participants from the city included, } \\
\text { therefore reasons from rural dwellers not } \\
\text { addressed. }\end{array}$ \\
\hline $\begin{array}{l}\text { Schäfer et al, } \\
\text { (2013) Germany } \\
\text { [32] }\end{array}$ & $\begin{array}{l}\text { 2009. Cross-sectional, observational study aiming } \\
\text { to describe patient-reported reasons for } \\
\text { nonparticipation in diabetes education and to } \\
\text { identify subgroups of non-participants in order to } \\
\text { improve recruitment strategies. } n=297 \text { adult } \\
\text { patients diagnosed with Type } 2 \text { diabetes who } \\
\text { were either participants or nonparticipants in } \\
\text { diabetes education were randomly recruited } \\
\text { from } 30 \text { primary care practices in Germany. } \\
\text { Exclusion criteria were a diagnosis of Type } 1 \\
\text { diabetes and aged } \geq 80 \text { years. All recruits } \\
\text { completed a patient health questionnaire and } \\
\text { comparisons were made between } 165 \\
\text { participants and } 132 \text { non-participants. }\end{array}$ & $\begin{array}{l}\text { Fully } \\
\text { compensated } \\
\text { by German } \\
\text { Statutory } \\
\text { Health } \\
\text { Insurance }\end{array}$ & $(n=132)$ & $\begin{array}{l}4 \text { typical subgroups of } \\
\text { nonparticipants were identified; } \\
\text { The informed and responsible, } \\
\text { the unconcerned without desire } \\
\text { for more information, the } \\
\text { uninformed but responsible and } \\
\text { the anxious and burdened with } \\
\text { psychosocial problems and } \\
\text { functional limitations. The main } \\
\text { actual reasons given by non- } \\
\text { participants for not attending } \\
\text { diabetes education were that } \\
\text { they already considered their } \\
\text { knowledge of diabetes to be } \\
\text { sufficient, felt diabetes } \\
\text { management is the } \\
\text { responsibility of their physician, } \\
\text { Other reasons included negative } \\
\text { feelings towards education and }\end{array}$ & Small sample size for a quantitative study. \\
\hline
\end{tabular}




\begin{tabular}{|c|c|c|c|c|c|}
\hline & & & & $\begin{array}{l}\text { groups, the purpose of course } \\
\text { being unclear, physical } \\
\text { demands and difficulty of the } \\
\text { course, vision and hearing } \\
\text { problems, timings of classes, } \\
\text { distance from venue and } \\
\text { financial issues were also } \\
\text { indicated as reasons for non- } \\
\text { attendance. }\end{array}$ & \\
\hline $\begin{array}{l}\text { Gucciardi et al, } \\
\text { (2012) } \\
\text { Canada } \\
\text { [33] }\end{array}$ & $\begin{array}{l}\text { 2008. Internet based survey. This study aimed to } \\
\text { explore patient utilisation of and barriers to } \\
\text { attending diabetes education centres (DEC). } n= \\
221 \text { adult patients diagnosed with either Type } 1 \text {, } \\
\text { Type } 2 \text { or pre-diabetes were recruited via an } \\
\text { internet survey. All participants completed a } \\
\text { questionnaire either online or a hard copy and } \\
\text { data were subjected to a mixed method analysis. }\end{array}$ & $\begin{array}{l}\text { Funded in } \\
\text { whole or in } \\
\text { part by the } \\
\text { Ministry of } \\
\text { Health }\end{array}$ & $(n=62)$ & $\begin{array}{l}\text { The most common reasons for } \\
\text { participants never attending the } \\
\text { diabetes education centre } \\
\text { included already receiving } \\
\text { education from their GP, lack of } \\
\text { information about diabetes } \\
\text { education courses from their } \\
\text { GP, feel they have enough } \\
\text { information and support to self- } \\
\text { manage their diabetes, } \\
\text { inconvenient scheduling, too ill, } \\
\text { access issues, language issues } \\
\text { and long waiting lists. }\end{array}$ & $\begin{array}{l}\text { Small sample size for a quantitative study, } \\
\text { limited to a small region of Ontario, } \\
\text { Canada. Attenders and non-attenders } \\
\text { characteristics combined. } \\
\text { No ethical approval or consent was } \\
\text { discussed. }\end{array}$ \\
\hline $\begin{array}{l}\text { Shaji et al, (2012) } \\
\text { India } \\
{[34]}\end{array}$ & $\begin{array}{l}\text { No study period reported. Cross-sectional study } \\
\text { which selected patients attending a tertiary care } \\
\text { Diabetes Centre for both, first visit or review } \\
\text { (after an absence of more than } 1 \text { year). All } \\
\text { subjects ( } n=756 \text { ) presenting at the hospital for a } \\
\text { non-acute visit were included in the study } \\
\text { irrespective of their attendance at diabetes } \\
\text { education. The study aimed to understand the } \\
\text { bias and barriers influencing the poor attendance } \\
\text { rates of patients towards diabetes education }\end{array}$ & Not specified & $(n=540)$ & $\begin{array}{l}\text { The main barriers to attendance } \\
\text { as reported by the non- } \\
\text { attenders were lack of time or } \\
\text { no time and not interested. } \\
\text { Problems with reading due to } \\
\text { eyesight complications in } \\
\text { addition to hearing problems } \\
\text { and stress. } \\
\text { Main perceived barriers to }\end{array}$ & $\begin{array}{l}\text { Neither ethical approval nor patient } \\
\text { consent reported. }\end{array}$ \\
\hline
\end{tabular}




\begin{tabular}{|c|c|c|c|c|c|}
\hline & $\begin{array}{l}\text { programmes. A survey questionnaire was used to } \\
\text { collect information on demographics, clinical } \\
\text { factors associated with diabetes, predictors of } \\
\text { attendance at diabetes education programmes } \\
\text { using both closed and open ended questions. } \\
\text { Responses to open ended questions were } \\
\text { recorded verbatim by the researchers. All other } \\
\text { data were analysed using SPSS. }\end{array}$ & & & $\begin{array}{l}\text { diabetes education were: - } \\
\text { Repetition of content, lack of } \\
\text { time, no interest, don't care, } \\
\text { denial, unaware of resources } \\
\text { and a combination of the above } \\
\text { reasons. }\end{array}$ & \\
\hline $\begin{array}{l}\text { Wadher, (2010) } \\
\text { UK } \\
\text { [12] }\end{array}$ & $\begin{array}{l}\text { 2010. Postal survey, which selected the last ( } \mathrm{n}= \\
\text { 200) patients ( } 100 \text { newly diagnosed with diabetes } \\
\text { and } 100 \text { with established diabetes) who had not } \\
\text { responded to an invitation to attend a DESMOND } \\
\text { programme. The aim of this service review was to } \\
\text { ascertain why such a high percentage }(65 \%), \\
\text { choose not to attend the DESMOND programme } \\
\text { and whether the programme could be altered to } \\
\text { accommodate more of these people. All } 200 \\
\text { patients were posted a short anonymous multiple } \\
\text { choice survey designed to address the aim. } \\
\text { Descriptive statistics were used to describe } \\
\text { reasons for non-attendance. }\end{array}$ & No cost & $(n=47)$ & $\begin{array}{l}\text { The main findings of this survey } \\
\text { for non-attendance at the } \\
\text { DESMOND programme were; } \\
\text { Timing of programme, already } \\
\text { knowledgeable, venue, length } \\
\text { of course, no referral letter } \\
\text { received, dislike of groups, no } \\
\text { reason given and access issues. }\end{array}$ & $\begin{array}{l}\text { Small sample size for a quantitative study } \\
\text { did not report patient characteristics nor } \\
\text { reported on ethical approval or consent. }\end{array}$ \\
\hline $\begin{array}{l}\text { Peyrot et al, } \\
\text { (2009) } \\
\text { USA } \\
{[35]}\end{array}$ & $\begin{array}{l}\text { No study period reported. Internet based survey. } \\
\text { This study aimed to investigate factors associated } \\
\text { with access to Diabetes Self-Management } \\
\text { Education (DSME) the perspective of not only the } \\
\text { patient ( } n=1169 \text { ) but also the educator ( } n= \\
1871 \text { ) and physicians }(n=629 \text { ). With respect to } \\
\text { the patient group only } n=508 \text { adult patients } \\
\text { diagnosed with both Type } 1 \text { and } 2 \text { diabetes who } \\
\text { had never attended a DSME programme } \\
\text { completed an online questionnaire which aimed }\end{array}$ & $\begin{array}{l}\text { Not specified } \\
\text { however, The } \\
\text { Affordable } \\
\text { Care Act (ACA) } \\
\text { in the USA is } \\
\text { intended to } \\
\text { help all } \\
\text { Americans } \\
\text { have health } \\
\text { insurance, but } \\
\text { to what extent }\end{array}$ & $(n=503)$ & $\begin{array}{l}\text { The main patient barriers to } \\
\text { DMSE self- reported by those } \\
\text { patients who never attended } \\
\text { were:- Don't think they need } \\
\text { education, can't fit into } \\
\text { schedule, insurance issues, } \\
\text { financial issues and access } \\
\text { issues. }\end{array}$ & $\begin{array}{l}\text { Minorities and those from lower } \\
\text { socioeconomic backgrounds were } \\
\text { under-represented. Did not report } \\
\text { ethical approval for study. }\end{array}$ \\
\hline
\end{tabular}




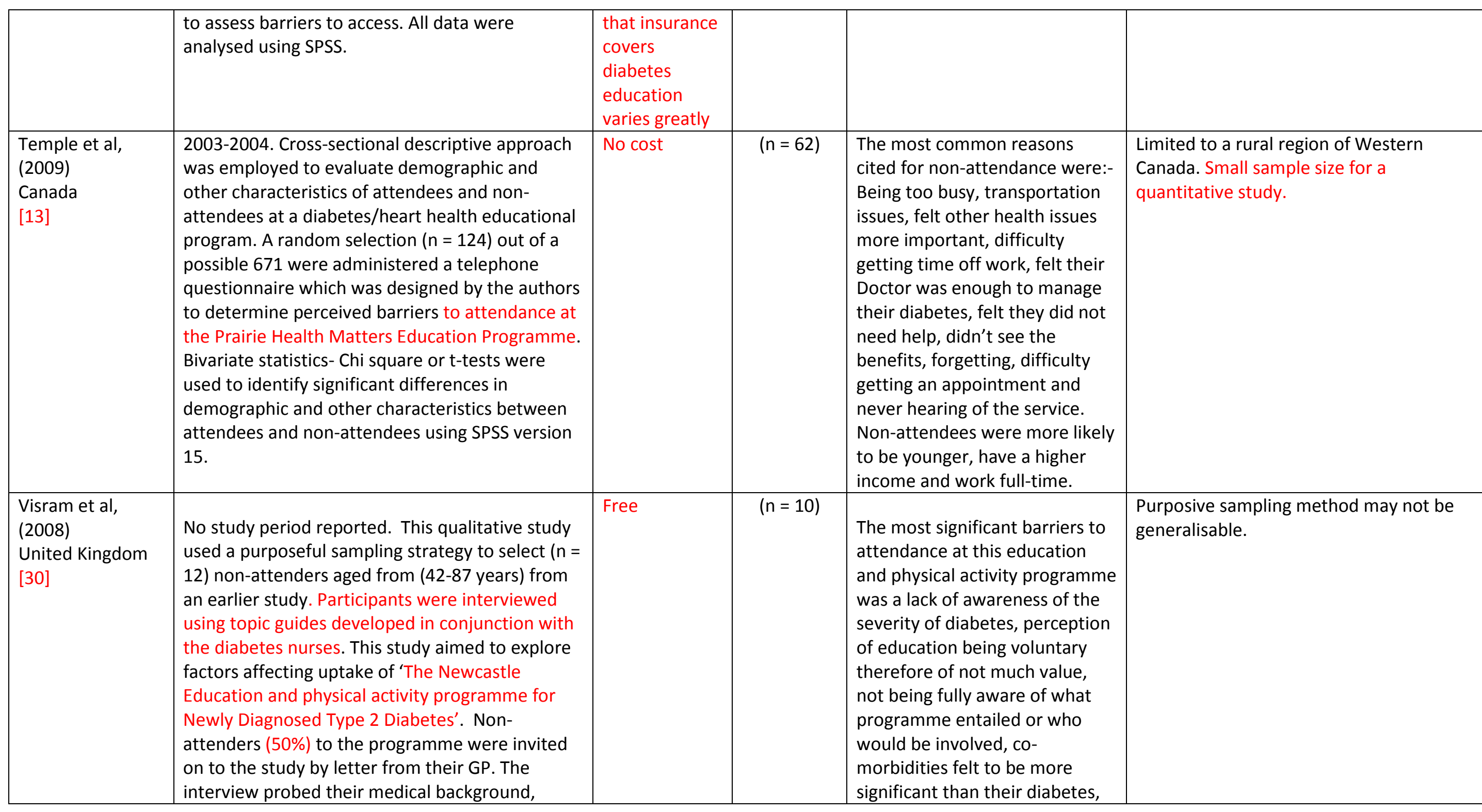




\begin{tabular}{|c|c|c|c|c|c|}
\hline & $\begin{array}{l}\text { quality-of-life, knowledge of diabetes and } \\
\text { reasons for non-attendance. Data were analysed } \\
\text { using a thematic content/framework } \\
\text { approached. }\end{array}$ & & & $\begin{array}{l}\text { that staff would not be aware of } \\
\text { their medical history, } \\
\text { programme too long and a } \\
\text { considerable fear of exercise. }\end{array}$ & \\
\hline $\begin{array}{l}\text { Rafique et al, } \\
\text { (2006) } \\
\text { Pakistan } \\
\text { [31] }\end{array}$ & $\begin{array}{l}\text { No study period reported. Exploratory, } \\
\text { descriptive research design was employed to } \\
\text { identify care and education issues among persons } \\
\text { with diabetes in Karachi and to assess the } \\
\text { knowledge, educational needs around their } \\
\text { diabetes and their willingness to learn. } A \\
\text { qualitative approach using semi-structured } \\
\text { questionnaires was used. } n=27 \text { participants (11 } \\
\text { men) and ( } 16 \text { women) diagnosed with either } \\
\text { Type } 1 \text { or } 2 \text { diabetes and aged } \geq 18 \text { years were } \\
\text { randomly selected from a larger study, all were } \\
\text { Pakistani nationals who had attended out-patient } \\
\text { clinics. }\end{array}$ & Not specified & $(n=14)$ & $\begin{array}{l}\text { The main themes pertinent to } \\
\text { education were: Doubt about its } \\
\text { usefulness, fear of being } \\
\text { overwhelmed and being unable } \\
\text { to understand what is being } \\
\text { communicated and using family } \\
\text { and friends to gain knowledge. } \\
\text { With the specific reasons given } \\
\text { by those who were not } \\
\text { interested in attending diabetes } \\
\text { education being:- Living too far } \\
\text { away from the hospital, unable } \\
\text { to come alone, no free time i.e. } \\
\text { other commitments. }\end{array}$ & $\begin{array}{l}\text { Does not describe ethical approval } \\
\text { however consent from was obtained from } \\
\text { participants. }\end{array}$ \\
\hline $\begin{array}{l}\text { Maine Dept of } \\
\text { Health and } \\
\text { Human Services, } \\
\text { (2006) } \\
\text { USA } \\
{[36]}\end{array}$ & $\begin{array}{l}\text { 2005-2006. The Maine Diabetes Prevention and } \\
\text { Control Programme Centre for Disease Control } \\
\text { (Maine CDC DPCP), conducted surveys of primary } \\
\text { care providers, diabetes educators and patients } \\
\text { with diabetes to determine barriers to referral } \\
\text { and participation in self-management } \\
\text { programmes. With respect to the diabetes } \\
\text { patients only, individuals diagnosed with } \\
\text { diabetes and registered with either a commercial } \\
\text { (Maine Care Program) or public funded (Anthem } \\
\text { health-insurance programme) were administered } \\
\text { a survey to measure their experience with } \\
\text { Diabetes Self-Management Education (DMSE) the }\end{array}$ & $\begin{array}{l}\text { Not specified, } \\
\text { however cost } \\
\text { was not listed } \\
\text { in the top five } \\
\text { barriers to } \\
\text { attendance } \\
\text { and the } \\
\text { information } \\
\text { was provided } \\
\text { by health } \\
\text { insurance } \\
\text { programmes. }\end{array}$ & $(n=841)$ & $\begin{array}{l}\text { Maine Care members reasons } \\
\text { for not attending diabetes } \\
\text { education were dislike of group } \\
\text { education, not interested, felt } \\
\text { they did not need information, } \\
\text { unaware of the education, } \\
\text { transportation issues, timings, } \\
\text { too busy, difficult to } \\
\text { understand, not convenient, } \\
\text { classes too long and having to } \\
\text { wait too long. } \\
\text { Anthem members reasons for }\end{array}$ & $\begin{array}{l}\text { Did not report statistical methods used } \\
\text { nor did they report patient characteristics } \\
\text { or ethical approval. }\end{array}$ \\
\hline
\end{tabular}




\begin{tabular}{|l|l|l|l|}
\hline & $\begin{array}{l}\text { survey included the topics of barriers and needs } \\
\text { to DMSE. } \mathrm{n}=2720 \text { responded to the insurance } \\
\text { providers survey of those }(\mathrm{n}=841) \text { reported they } \\
\text { did not attend Diabetes Education. The analysis } \\
\text { was conducted by the Muskie School of Public } \\
\text { Service however, the methods used nor patient } \\
\text { Characteristics were not reported. }\end{array}$ & $\begin{array}{l}\text { not attending education were: } \\
\text { felt they could manage on their } \\
\text { own, timings not convenient, } \\
\text { don't need information, too } \\
\text { busy, don't like groups, no } \\
\text { insurance/too expensive, need } \\
\text { more info, not interested, info } \\
\text { doesn't meet needs, } \\
\text { transportation issues and } \\
\text { having to wait too long. } \\
\text { Therefore } 2 \text { themes emerged. } \\
\text { Consumer perceptions, access } \\
\text { issues }\end{array}$ \\
\hline
\end{tabular}


Table 2. Themes, categories and reasons that emerged in review.

\begin{tabular}{|c|c|c|}
\hline Overarching themes & Categories of reasons & Reasons \\
\hline \multirow[t]{3}{*}{ Those who could not go } & Logistical reasons & $\begin{array}{l}\text {-Lack of transport } \\
\text {-Venue too far away } \\
\text {-No parking at venue } \\
\text {-Length of programmes } \\
\text {-Timings of programmes unsuitable } \\
\text {-More pressing commitments e.g. family and/or work }\end{array}$ \\
\hline & Medical reasons & $\begin{array}{l}\text {-Other disabilities or illnesses preventing them from } \\
\text { attending SDE. } \\
\text {-Unable to come alone }\end{array}$ \\
\hline & Financial reasons & $\begin{array}{l}\text {-Not having any or insufficient health insurance cover } \\
\text {-Unable to afford travel and/or costs associated with } \\
\text { getting to venue. }\end{array}$ \\
\hline \multirow[t]{4}{*}{ Those who will not go go } & No perceived Benefit & $\begin{array}{l}\text {-Feel there is no perceived benefits to be gained } \\
\text {-Not seen as high priority. } \\
\text {-Physicians Influences. } \\
\text {-Already satisfied with care receiving }\end{array}$ \\
\hline & Knowledge & $\begin{array}{l}\text {-Know enough already } \\
\text {-Feel they already receive adequate information from } \\
\text { physician/GP } \\
\text {-Feeling there is no need to be educated as they don't } \\
\text { perceive a problem. } \\
\text { - Lack of information on programmes } \\
\text {-Unaware of available programmes } \\
\text {-Programmes not promoted by health care } \\
\text { professionals. }\end{array}$ \\
\hline & Emotional & $\begin{array}{l}\text {-Negative feelings of diabetes education } \\
\text {-Negative feelings of groups } \\
\text {-Don't want to know side effects of diabetes. } \\
\text {-Fear of excessive demands. } \\
\text {-Denial } \\
\text {-Don't want anyone to know. }\end{array}$ \\
\hline & Cultural & $\begin{array}{l}\text {-Literacy /language/cultural problems } \\
\text {-Those with no reason/not interested and/or don't } \\
\text { know why they won't go. }\end{array}$ \\
\hline
\end{tabular}

